\title{
THEOPHYLACT SIMOCATTA REVISITED. A RESPONSE TO ANDREAS GKOUTZIOUKOSTAS
}

\author{
FLORIN CURTA \\ University of Florida. U.S.A
}

\begin{abstract}
In a reply to a previous article published in Byzantion Nea Hellás, the Greek historian Andreas Gkoutzioukostas has claimed that in a passage in Book VIII of Theophylact Simocatta's History, the word Sklavinia was used as an adjective, not as a noun, and that the Byzantine historian frequently used adjectives derived from ethnic names. This article is a demonstration that both claims are in fact wrong, as Theophylact had very precise reasons for avoiding adjectives derived from ethnic names. Such reasons have much more to do with the narrative strategies that he employed than with the norms of the Greek language. His usage of Sklavinia is also mirrored by Hugeburc of Heidenheim's transcription of St. Willbald's account of his pilgrimage to the Holy Land.
\end{abstract}

Keywords: Theophylact Simocatta, Slavs, ethnicity, barbarians, Vita S. Willibaldi, Theophanes

\section{TEOFILACTO SIMOCATES REVISADO. UNA RESPUESTA A ANDREAS GKOUTZIOUKOSTAS}

Resumen: En una respuesta a un artículo anterior publicado en Byzantion Nea Hellás, el historiador griego Andreas Gkoutzioukostas ha afirmado que en un pasaje del Libro VIII de la Historia de Teofilacto Simocates, la palabra Sklavinia se usa como adjetivo, no como sustantivo, y que el historiador bizantino frecuentemente usa adjetivos derivados de nombres étnicos. Este artículo es una demostración de que ambas afirmaciones son de hecho erróneas, ya que Teofilacto tenía razones precisas para evitar adjetivos derivados de nombres étnicos. Tales razones tienen mucho más que ver con las estrategias narrativas que empleó que con las normas de la lengua griega. Su uso de Sklavinia también se replica en la transcripción que Hugeburc de Heidenheim hace del relato de S. Willbald acerca de su peregrinación a Tierra Santa.

Palabras clave: Teofilacto Simocates, eslavos, etnicidad, bárbaros, Vita S. Willibaldi, Teófanes 
Recibido: 3.07.15 Aceptado: 27.07.15

\section{Correspondencia: Florin Curta.}

Email: fcurta@ufl.edu

University of Florida, Department of History. 202 Flitn Hall, P.O. Box 117320. Gainesville, FL 32611-7320. Phone: + 1 (352) 273-3367. FAX: + 1 (352) 392-6927

A $t$ an international conference held in Thessaloniki in November

2013, Andreas Gkoutzioukostas has presented a paper on the use of the word "Sklavinia" in the History of Theophylact Simocatta. Recently published in the conference proceedings, the paper is meant to be a reply to my 2011 article in Byzantion Nea Hellás (Curta 2011; Gkoutzioukostas 2015). I am grateful to the editors for this chance to respond. My purpose, however, is not to engage in polemics over minute details, but to raise broader questions about the narrative strategies employed in Theophylact's History, and especially about his lack of adjectives derived from ethnic names.

It is important to recapitulate the history of this debate. Eight years ago, Evangelos Chrysos has claimed that in a passage in Book VIII of Theophylact's History, the word Sklavinia is an adjective modifying the noun translated into English as "horde," and not a noun, i.e., the name of a territory or country. Chrysos had two main arguments to support his interpretation. First, an argumentum ad auctoritatem: the text's first editor, Carl de Boor, as well as its translators into the English language, Mary and Michael Whitby, have taken the word to be an adjective ${ }^{1}$. Second, Chrysos believed that the adjective sklavinios must have existed in the Greek version of the Vita Methodii, an original work otherwise written in Old Church Slavonic (Chrysos 2007, 126 with n. 8). In my 2011 paper, I have showed the weakness of the latter argument, but also pointed out that there is no adjective sklavinios in the Greek language at all (Curta 2011, 89). Moreover, I pointed out that there is actually in Theophylact Simocatta's History no adjective derived from the noun $\Sigma \kappa \lambda \alpha v \eta v o i / \Sigma \kappa \lambda \alpha \beta \eta v o i$. Hordes of Slavs are mentioned several times in the text, but there is no Slavic horde. As a matter of fact, the word $\pi \lambda \eta \theta \dot{v} \varsigma$ or its equivalent $\pi \lambda \tilde{\eta} \theta v o \varsigma$, both translated

1 Gkoutzioukostas adds to the list of authorities favoring Chrysos's interpretation: Despoina Tsouklidou, Johannes Koder, Leslie Brubaker and John Haldon (Gkoutzioukostas 640). 
into English as "horde," never appear in Theophylact's History in the company of an adjective derived from an ethnic name (Curta 2011, 90). My conclusion was, therefore, that Sklavinia in the passage of Book VIII of Theophylact's History actually refers to the "land of the Slavs" (Curta 2011, 91). The reason for Theophylact's use of this proper noun is the narrative need to distinguish for his audience between different lands on the northern bank of the river Danube, some controlled by Avars, others by more or less independent Slavs (Curta 2011, 93). This, in other words, was the result of a particular narrative strategy (as well as of Theophylact's bombastic style), not of some administrative usage, such as attested only in the $9^{\text {th }}$ century.

Gkoutzioukostas attacks first my third argument concerning Theophylact's use of the word $\pi \lambda \eta \theta \dot{v} \varsigma / \pi \lambda \tilde{\eta} \theta$ o $\varsigma / \pi \lambda \tilde{\eta} \theta \eta$. According to him, the noun is "normally" followed by a genitive of content, which supposedly contradicts my interpretation (Gkoutzioukostas 642). It is not clear what "normally" actually means for Gkoutzioukostas, but there are plenty of examples in Greek of the noun $\pi \lambda \eta \theta \dot{v} \varsigma / \pi \lambda \tilde{\eta} \theta$ oc/ $/ \lambda \tilde{\eta} \theta \eta$ being used without any genitive of content. Much like in English, one can speak in Greek of a "multitude" without mentioning its content. Theophylact offers some good examples. The reduction in the remuneration of the soldiers gathered in Monocarton (near Edessa) in 588 led to a rebellion as soon as it "became clear to the whole throng" ( $\dot{\varepsilon} \varsigma \tau$ iò

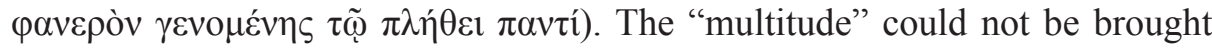
to its senses even when Priscus decided to parade an acheiropoieton image

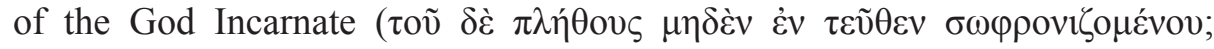
Theophylact Simocatta 111; English translation from Whitby and Whitby $73)^{2}$. A Roman general asks the "multitude" for advice on an upcoming battle (Theophylact Simocatta 123), while a Persian king crosses the Euphrates with a great "multitude" (Theophylact Simocatta 91). In Persia, much like in the Roman Empire, the "whole multitude" ( $\dot{\eta} \pi \tilde{\alpha} \sigma \alpha \pi \lambda \eta \theta \hat{v} \varsigma$ ) rose in rebellion upon learning that Hormisdas had cut the customary distributions to the contingents from the royal treasuries (Theophylact Simocatta 149; English translation from

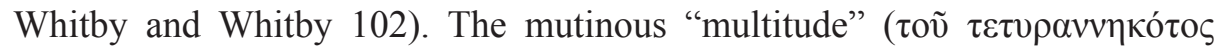
$\pi \lambda \dot{\theta} \theta$ ov $\varsigma$ ) under Phocas plunders "all the horses grazing outside the city" of Constantinople (Theophylact Simocatta 298; English translation from Whitby and Whitby 221). One may argue that in all those cases, the implication is that the "multitude" consists of soldiers, but that definitely does not apply to the

2 For Theophylact's account of the 588 rebellion, see Krivushin 1991 52-53. 
passage describing Emperor Maurice celebrating Candlemas "with the throng" ( $\dot{\alpha} \pi$ ò $\tau$ oṽ $\pi \lambda \eta \dot{\theta} \theta$ ovs; Theophylact Simocatta 291) or to that in which we are told that the "multitude is uneducated and is frenzied by changes for the worse"

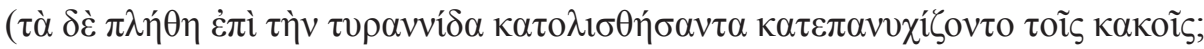
Theophylact Simocatta 301; English translation from Whitby and Whitby 223) 3 .

Gkoutzioukostas also claims that in Theophylact's text the noun $\pi \lambda \eta \theta u ́ \varsigma$ may be modified by adjectives derived from ethnic names. As proof, he cites several passages with the adjective "Babylonian" (B $\alpha \beta 1 \lambda \omega v i ́ \alpha)$.

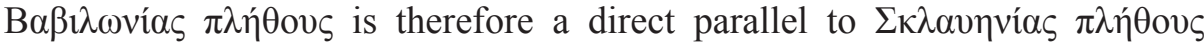
(Gkoutzioukostas 643). But B $\alpha \beta i \lambda \omega v i \alpha$ is not in fact an adjective derived from an ethnic name, at least not as Gkoutzioukostas imagines $\Sigma \kappa \lambda \alpha v \eta v i ́ \alpha$ to be. First, $B \alpha \beta \imath \lambda \omega v i \alpha$ appears in Theophylact's History as a proper noun, i.e., the name of a country. The Romans, for example, "exploited the Persian failures and marched towards the interior of Babylonia" (Theophylact Simocatta 140; English translation from Whitby and Whitby 95). The future emperor Maurice

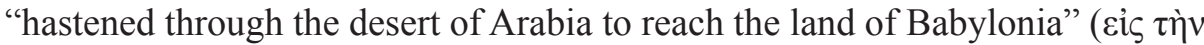
$\mathrm{B} \alpha \beta i \lambda \omega v i \alpha v$; Theophylact Simocatta 146; English translation from Whitby and Whitby 99) ${ }^{4}$. Babylon(ia) is made of different parts, and one can depart from it, both indications of a clearly defined territory (Theophylact Simocatta 283

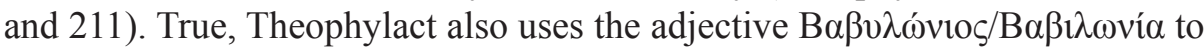

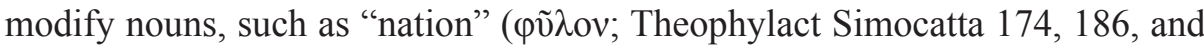
216; English translation from Whitby and Whitby 121, 130, and 153), "scepter" (Theophylact Simocatta 184), "tyrant" (Theophylact Simocatta 185), "force" or, indeed, "multitude" (Theophylact Simocatta 141 and 180). But in all those cases, the meaning of the adjective is territorial, not ethnic. In other words, $\tau \tilde{\eta} \varsigma$

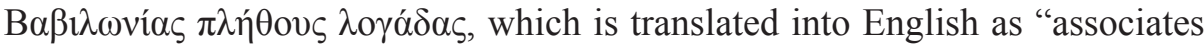
from the Babylonian army" actually stands for "associates from the army from/ of Babylon(ia)" (Theophylact Simocatta 180; English translation from Whitby

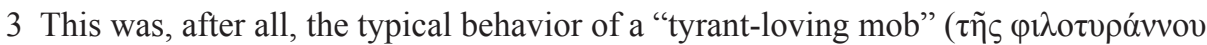
$\pi \lambda \eta \dot{\theta o v \varsigma ;}$ Theophylact Simocatta 308; English translation from Whitby and Whitby 230).

4 One can move "against Babylon(ia)" (cis $\tau \tilde{\eta} \varsigma$ B $\alpha \beta \imath \lambda \omega v i ́ \alpha$; Theophylact Simocatta 184; English translation from Whitby and Whitby 128), and some are "renowned

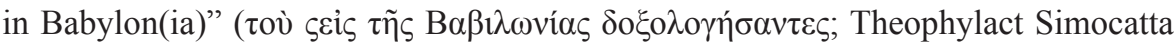
187; English translation from Whitby and Whitby 130). For the Middle (Byzantine) Greek features of Theophylact's use of the preposition cis, see Olajos 1990-1992, 183. 
and Whitby 125). The adjective, in other words, is derived from the name of a country, and not from an ethnic name. To be sure, in this case the ethnic name ("Babylonians") also derives from the name of the country, which is perhaps why Gkoutzioukostas regards $B \alpha \beta \imath \lambda \omega v i ́ \alpha$ as an ethnic adjective, perfectly similar to $\Sigma \kappa \lambda \alpha v \eta v i ́ \alpha$. However, when writing that "the use of the adjective ' $\Sigma \kappa \lambda \alpha v \eta v i ́ \alpha$ ' is entirely consistent with Theophylact's formulation and the use of ethnic adjectives" (Gkoutzioukostas 644), Gkoutziokostas does not seem to be aware of the implications of his remark. If $B \alpha \beta 1 \lambda \omega v i ́ \alpha$ and $\Sigma \kappa \lambda \alpha v \eta v i ́ \alpha$ are both ethnic adjectives, since the former derives from the name of the country (Babylon), the latter should have a similar origin. In other words, there should be a country also called $\Sigma \kappa \lambda \alpha v \eta v i ́ \alpha$, with a clearly defined territory, much like B $\alpha \beta \imath \lambda \omega v i \alpha$. The adjective $\Sigma \kappa \lambda \alpha u \eta v i ́ \alpha$ would have to be derived from the name of a country named $\Sigma \kappa \lambda \alpha v \eta v i ́ \alpha$. The risk of a circular argument seems to have completely escaped Gkoutzioukostas's attention.

Without specifically calling it an ethnic adjective modifying the noun

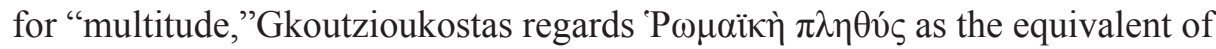
$\pi \lambda \eta \theta \hat{\varsigma} \varsigma \mathrm{P} \omega \mu \alpha i \omega v$ (Gkoutzioukostas 642). He is of course right. Besides a $\pi \lambda \eta \theta \hat{\varsigma} \varsigma$ of Romans, Theophylact's History offers examples of a Roman $\pi \lambda \eta \theta u$ (e.g.,

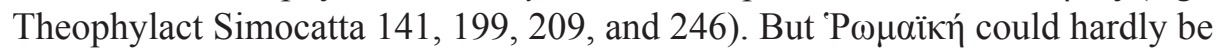
considered an ethnic adjective, even though in his bombastic style, Theophylact not only calls the Persians Medes, Parthians, Babylonians, and Chaldeans, but also the Romans Latins (Treadgold 2007, 338)5. It is worth exploring further

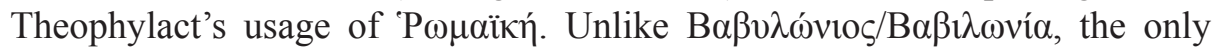
noun that $\mathrm{P} \omega \mu \alpha \ddot{\kappa} \kappa \eta$ modifies in the History is $\pi \lambda \eta \theta u ́ s$. That noun is always employed for an army. Without exception, a $\pi \lambda \eta \theta u ́ \varsigma$ from Babylon(ia) is also an army. Those are called "Roman" and "Babylonian" armies, respectively, because they came from, and belonged to well established, "legitimate" states. In all other cases in which he uses $\pi \lambda \eta \theta \dot{v} \varsigma$ with an ethnic name, Theophylact does so because to employ the ethnic adjective would imply that those were armies in some way similar to those from/of the Roman Empire and Sassanian

5 To be sure, the Romans are said at one point to be an ethnos ( $\tau \tilde{\omega} \nu$ 'P $\omega \mu \alpha i \omega v$ है $\theta v o$; Theophylact Simocatta 223). But Theophylact puts those words in the mouths of the three Sclavenes from the shore of the western Ocean, who knew that they also belonged to an ethnos. In other words, Theophylact makes the Sclavenes look ignorant, for they inadvertently equate the Roman Empire with their "nation" (Curta 2008, 162). For the episode of Emperor Maurice's encounter with the three Sclavenes from the shore of the western Ocean, see Wołoszyn. 
Persia. Mary and Michael Whitby, who translated the History into English, understood this assumption perfectly when choosing the word "horde" for translating $\pi \lambda \eta \theta \dot{\varsigma} \varsigma / \pi \lambda \tilde{\eta} \theta$ os/ $/ \lambda \tilde{\eta} \theta \eta$ in any context not referring to either Romans or Persians. There is, in other words, no Roman or Persian "horde". Nor can one conceive of a Sclavene "army," as all "multitudes" of barbarians are in fact just "hordes". The lack of an ethnic adjective to modify the noun $\pi \lambda \eta \theta v$ c/ $\pi \lambda \tilde{\eta} \theta$ oc/ $/ \pi \lambda \tilde{\eta} \theta \eta$ has therefore a much deeper and serious explanation than just Theophylact's idiosyncratic style. Using 'P $\omega \mu \alpha \ddot{\kappa} ฑ \dot{~ a n d ~ B ~} \alpha \beta \imath \lambda \omega v i ́ \alpha$, but not $\Sigma \kappa \lambda \alpha u \eta v i ́ \alpha$ as adjectives modifying $\pi \lambda \eta \theta v ́ \varsigma / \pi \lambda \tilde{\eta} \theta$ o $/ / \pi \lambda \tilde{\eta} \theta \eta$ is a way to say that in the former case one deals with well organized and trained troops, while the latter refers to a chaotic agglomeration of military forces. People with ethnic names cannot possibly have armies, because they are barbarians, a word that Theophylact often uses together with "multitude." There is no Avar or Turkic army, because there is no Avaria or Tourkia (Curta 2011, 94). At least in the case of the Avars, the absence of a proper name for their country is plainly explained in Theophylact's History. A fake letter from Emperor Maurice to Priscus, who was besieged in Tzurullon in 588, demands that the Chagan "make an ill-fated and ignominious retreat with numerous losses to the country which he was assigned by the Romans" (Theophylact Simocatta 229; English translation from Whitby and Whitby 166). Five years earlier, Comentiolus, the imperial envoy that Emperor Maurice sent to the Avars, put it even more bluntly when addressing the Chagan: "Go back, then, to your land, which indeed the Romans lavished on you, and do not divert your power beyond your borders!" (Theophylact Simocatta 50; English translation from Whitby and Whitby 27). There is no Avaria, because that land is in fact Roman, having been given only temporarily to the Avars by the emperor.

It has long been noted that Theophylact has a very vague notion of Balkan geography (Treadgold 2007, 338; Wołoszyn 46). He most certainly has not seen with his own eyes many of the places mentioned in his History. However, he was clearly aware of the role the river Danube played as a frontier separating the Empire from barbarians. Demanding that the Avars return to their lands north of the river, Comentiolus asks the Chagan to "show greater respect to this Roman territory of ours" (Theophylact Simocatta50; English translation from Whitby and Whitby 27). On the other hand, Theophylact puts words in Chagan's mouth that bespeak his (Theophylact's) preoccupation with neatly delineated territories. When meeting Priscus on the island of Singan, "which is situated in the Ister's stream thirty miles distant from the city of Singidunum," 
the Chagan rhetorically asks the general: "What are you doing, Romans, in the land which is mine? Why have you extended your steps beyond what is proper? ${ }^{6}$ The Ister is foreign to you, its swell hostile" (Theophylact Simocatta 263; English translation from Whitby and Whitby 193). Through the peace of Drizipera (598), the river Danube became an "intermedium ( $\mu \varepsilon \sigma i \tau\rceil)$ ) between Romans and Avars, but there was provision for crossing the river against the Sclavenes" (Theophylact Simocatta 273; English translation from Whitby and Whitby 201) ${ }^{7}$. In other words, although the lands north of the river Danube were recognized as being under Avar control, the Romans were allowed to cross the river in order to attack those lands that were inhabited by Slavs. There was no Avaria north of the river Danube, because one part of it was a formerly Roman territory that had been temporarily assigned to the Avars, while the other was

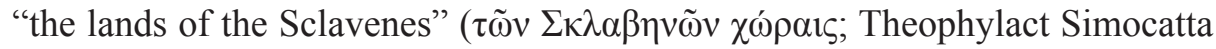
$218)^{8}$. Theophylact introduces this phrase precisely at the point where he needs to explain that the Roman troops campaigning against the Slavs north of the river Danube had not yet returned when they received the order from Maurice to winter there. In the preceding paragraph of his History, Theophylact was at pains describing three concomitant movements of armies, all in relation to the river Danube. The Roman troops were north of that river, but in the "lands of the Sclavenes" and not in those directly controlled by the Avars. A second, Avar army moved at the same time against the Antes, who were located to the east from the "lands of the Sclavenes" and had long been allied with the Romans. It is quite clear that in order to reach the lands of the Antes, the Avars needed to move along the river Danube, either on the northern or on the southern bank. The northern bank, where the Sclavenes lived, would have been the shorter way, but the Roman troops were there at that time, campaigning against the Sclavenes. It is therefore possible, although Theophylact does not explicitly say so, that the Avars moved along the southern bank through what was, at least according to the terms of the peace of Drizipera, Roman territory. A third movement was taking place exactly at this point, namely large numbers of Avars defecting to

6 A direct parallel to Comentiolus' earlier request to the Chagan: "do not divert your power beyond your borders" (Theophylact Simocatta 50; English translation from Whitby and Whitby 27).

7 For the Danube as $\mu \varepsilon \sigma i$ in $\varsigma$, see Patoura 2002, 410.

8 Most likely inspired by the plural employed at this particular point, a recent translation

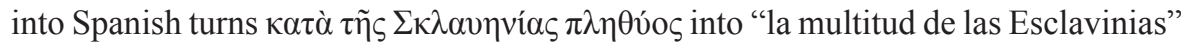
(Morfakidis Filactós and Casas Olea 103). 
the Romans, most likely through the Balkan provinces of the Empire, and not to the Roman armies campaigning north of the river Danube (Pohl 2002, 161). This is in fact the context in which Theophylact employed the word $\Sigma \kappa \lambda \alpha v \eta v i ́ \alpha$. He did so in order to give territorial precision to the description of the confusing events that took place in the summer of 602 (Curta 2011, 93; Malinovská 2013, $61)^{9}$.

Gkoutzioukostas disagrees. According to him, "the use of the noun ' $\Sigma \kappa \lambda \alpha v \eta v i ́ \alpha$ ' would not serve Theophylact's narrative in any way, since it is explicitly stated where the attacks of the Byzantine army took place" (Gkoutzioukostas 645). But this is obviously not so. In the previous sentence, we are told that Peter, Emperor Maurice's brother was ordered to leave Adrianople and to "make the crossing of the Ister" (Theophylact Simocatta, 292-293; English version from Whitby and Whitby 217). Starting from Adrianople, Peter could have moved in various directions to the north or northwest in order to reach the Danube, and the crossing could have taken place at any point along the river. True, the Roman army was about to campaign on the other side of the Danube, but it is not at all clear where exactly - whether in the lands under the direct control of the Avars, or in those of the Sclavenes. That Peter had the latter in mind results primarily from the logic of Theophylact's narrative. Before mentioning the order Peter received in 602 from Maurice, Theophylact has just finished the story of Peter "taking position in the Dardanian province, for he had

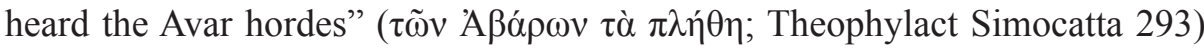
were gathered at "the place called Cataracts" (English version from Whitby and Whitby 216-217). According to Teréz Olajos, those events took place in the summer or at the beginning of Fall 601 . The symmetry is quite obvious. At that time, the action was against a particular kind of hordes, namely those of the Avars. The mention of Dardania and the Cataracts (most likely the Iron Gates sector of the river Danube) leaves no doubt about where the attack of the Byzantine army took place - the lands now in southwestern Romania and northern Serbia. The following summer, Peter moved from Adrianople to the Danube, but this time his action was against a different horde, namely that in Sklavinia. Instead of "horde of Sclavenes," Theophylact uses here a name he has invented for the land of the Slavs derived from the very name he used for them in the History. This may have something to do with the fact that Sclavenes were also known to have lived in the lands under the direct control of the Avars.

9 For the chronology of those events, see Olajos 1988, 172. 
Before the events of 601, Priscus had fought the Avars in their own territory and had taken 8,000 Sclavene prisoners, in addition to 3,000 Avars and 6,200 other barbarians (Theophylact Simocatta 211-213). Sklavinia, in other words, was not just any land inhabited by the Slavs, but specifically that located across the lower course of the Danube, in the southern and southeastern region of present-day Romania. The description of the events of 602 made the use of the name Sklavinia necessary, especially if Theophylact wanted to avoid repeating

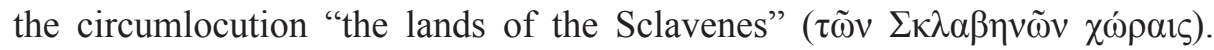
Indeed, one of Theophylact's key stylistic features is the obsession to avoid monotony and repetition, even at the risk of obscuring the meaning of his own words (Olajos 1982, 160). Sklavinia was a solution to that problem, but by no means the only example of Theophylact's style, which Warren Treadgold has characterized as "so ludicrously convoluted and ornate that it bothered even Photius, who had more tolerance for affectation than most modern critics" (Treadgold 2007, 337). Theophylact has created many new words, all marked as hapax legomena in Carl de Boor's Index nominum (Olajos 1990-1992, 185). In other words, the invention of Sklavinia is nothing unusual, but instead a narrative strategy most typical for Theophylact.

The second attestation of the word in a chronological order is in a Latin source, the Life of St. Willbald written in the 770s by a nun from the Abbey of Heidenheim named Hugeburc. On his way to the Holy Land, Willibald embarked at Syracuse in Sicily and then "reached the city of Monemvasia, in the land of Slavinia (in Slawinia terrae)" (Vita Willbaldi 93; English translation from Noble and Head $151^{10}$ ). Against Chrysos's interpretation of this passage as reflecting, again, an adjectival use of the word ("in the Slavic land," instead of "in the land of Slavinia"), I have pointed out in my 2011 article that Slawinia cannot be an adjective modifying the noun terra, because there is no grammatical case concord between the two words. Gkoutzioukostas takes me to task for that. According to him, my interpretation is not consistent with the "syntax and the position of the word 'Slawinia' between the preposition 'in' and the noun 'terrae"' (Gkoutzioukostas 645) ${ }^{11}$. Ignoring completely the question of the grammatical case concord (much like Chrysos's wrong use of the Life of Methodius), Gkoutzioukostas believes instead that his emphasis on syntax and the position of Slawinia is a sufficient argument in favor of treating the word as

10 For a similar Russian translation, see Ronin 439.

11 It remains unclear what exactly are "the grammatical types of the terms." 
an adjective. However, if one is to take him seriously, then the adjective should follow the noun, for in Latin the adjective goes after the noun, unless there is some special, rhetorical or poetic emphasis. This is precisely the order in which the noun "land" (terra) and the adjective "Slavic" (Sclauinica) are combined in the text of a charter that Emperor Otto III granted in 985 for the benefit of Abbess Mathilda of Quedlinburg (Sickel 403) ${ }^{12}$. As with $\Sigma \kappa \lambda \alpha v \eta v i ́ \alpha$ in Greek, Slawinia is nowhere attested in Latin as an adjective (Ronin 439). Much like in Greek, the preferred Latin adjective derived from the ethnic name of the Slavs is Sclauinicus (-a). In order to accept Gkoutzioukostas' assurance that "it is more probable that in the Vita of St. Willibald the term 'Slawinia' is an adjective," one would therefore have to presume that two different authors-Theophylact Simocatta and Hugeburc - writing in two different languages, at a great distance from each other both in space and in time, invented the same word to render a quality of being Slavic, for which there were already corresponding words in both languages. Moreover, it is likely that Hugeburc learned about Slawinia from Willibald himself, so one would have to presume that the word is his creation - a very unlikely proposition. That Hugeburc preferred the awkward construction in Slawinia terrae to a periphrasis such as ad urbem que dicitur Reggia, in insulam nomine Choo, or ad villam magnam qui vocatur Figila may not be just the result of her writing style, with "exuberantly crammed, complex periods, enhanced rare words and phrases, new formations and coinages" (Dronke 33). Given that the last verb of the sentence containing in Slawinia terrae is venerunt - a verb of motion - the correct Latin should have been in terram, followed by a proper name in nominative or genitive. There is in fact a clear example of that construction on the same page of the standard edition of the Vita Willibaldi ${ }^{13}$. Hugeburc did not use the accusative (terram), but the dative (terrae), because the construction was meant to be an explanatory equivalent for urbs Manafasia. In that case, the correct case for terra preceded by the preposition in should have been the ablative, not the dative. In other words, the correct, complete sentence was as follows: "reached the city of Monemvasia, which is in the land(s) of Slavinia" ("venerunt... ad urbem Manafasiam, quae

12 The same order appears in the $12^{\text {th }}$-century Deeds of the Princes of the Poles by an unknown author (Gallus Anonymus): "Igitur terra Sclauonica ad aquilonem hiis regionibus suis partialiter divisivis sive constitutivis existens..." (Knoll and Schaer15).

13 Vita Willbaldi 93: navigaverunt in terram Galabriae. 
in Slawinia terra est" ${ }^{14}$ ) Hugeburc's mistake clearly shows that, to her, Slawinia was not an adjective modifying terra, for she would have otherwise placed it in the dative as well ("Slawiniae"). Such an interpretation is supported by the examination of a similar construction elsewhere in the text of Vita Willibaldi. To explain the location of the tomb of St. Ananias of Damascus, Hugeburc wrote: "et sanctus Annanias requiescat ibi; illud est in terra Syrim" (Vita Willbaldi 95). In terra Syrim is a mirror image of in Slawinia terrae, as Syrim (presumably the accusative form of Syria, Syriam) is just as awkwardly associated with the noun terra in ablative as Slawinia is to the same word in dative ${ }^{15}$. Far from being an adjective, Slawinia is a country name, which is exotic enough for Hugeburc to create serious problems of declension.

The main reason for which both Evangelos Chrysos and Andreas Gkoutzioukostas persist in claiming that "for the period up to the fourth quarter of the eighth century we have no reference in Latin or in Greek sources for Sclaviniae as concrete geographical and political units" (Chrysos 2007, 132) is to have the earliest attestation of $\Sigma \kappa \lambda \alpha u \eta v i ́ a$ in the Chronography of Theophanes the Confessor. Gkoutzioukostas adds that the $9^{\text {th }}$-century usage is to be explained in terms of "the new military and provincial administration system of the middle Byzantine state" being already established, which made room for "certain technical terms relating to its regional organization," such as $\Sigma \kappa \lambda \alpha v \eta v i ́ \alpha$ (Gkoutzioukostas 646). However, the appearance of $\Sigma \kappa \lambda \alpha v \eta v i ́ \alpha$ in Theophanes' Chronography was not influenced by any administrative usage. The term does not appear on any seals, and is most likely a literary, not administrative construct. Moreover, much of Theophanes' coverage of the reigns of Constans II, Justinian II, and Constantine V-all emperors known to have launched military expeditions against territories called $\Sigma \kappa \lambda \alpha v \eta v i ́ \alpha-$ is based on earlier sources: the Concise Chronicle of Trajan the Patrician (for the period between 629 and 720) and its continuation by an unknown author, possibly the future patriarch Tarasios (for the period 721-781; Treadgold 2013, 9-10, 18, and 68). The various mentions of $\Sigma \kappa \lambda \alpha u \eta v i ́ \alpha(1)$ in the Chronography may well be from those, now lost sources, in which case they are to be dated earlier than the

14 For Hugeburc's (mis)use of the relative pronoun, see Gottschaler 1973, 44-45.

15 See also Vita Willbaldi 94: "et caput illius [of St. John the Baptist] fuit ibidiu, hoc est in Syrim." Elsewhere, one reads of the city of Salamaitha; "illa est in extremis finibus Syrium" (Vita Willbaldi 100). Just before that, however, Hugeburc used the correct form of the country name: "ad urbem Emesam in Syriae" (Vita Willbaldi 100). 
$9^{\text {th }}$ century, namely to the $8^{\text {th }}$-century. This would in turn dovetail quite nicely with Hugeburc's mention of Slawinia, which is also of an $8^{\text {th }}$-century date. The conclusion seems inescapable: although the territorial meaning of the word was firmly established only in the $9^{\text {th }}$ century, when there is a clear shift towards its political interpretation (as referring to a territory that was within the Empire), $\Sigma \kappa \lambda \alpha u \eta v i ́ \alpha$ may have well been occasionally used in the historiography of the $8^{\text {th }}$ century in much the same way as in Theophylact Simocatta's History, namely to refer to the land(s) of the Slavs situated outside the Empire. Once upon a time, Evangelos Chrysos was convinced that in Theophylact's eyes, the territory north of the river Danube was "the land of the Slavs" (Chrysos 1987, 36). Twenty years later, his opinion has radically changed: the Slavs are now landless, since $\Sigma \kappa \lambda \alpha v \eta v i ́ \alpha$ presumably refers not to "a geographical or political unit, but a group of people, the Slavene crowd, the horde" (Chrysos 2007, 126). What caused this change of mind remains unclear, and Andreas Gkoutzioukostas's gallant defense of Chrysos's "updated" position does not help elucidate the mystery. As a matter of fact, it only adds to the confusion. 


\section{BIBLIOGRAPHICAL REFERENCES}

\section{Primary sources}

KNOLL, PAUL W. AND SCHAER, FRANK (2003). Gesta Principum Polonorum. The Deeds of the Princes of the Poles. Budapest/New York: Central European University Press.

SICKEL, THEODOR (1893). Diplomata regum et imperatorum Germaniae, vol. 2. Hannover: Hahn.

THEOPHYLACT SIMOCATTA (1972). Historiae, Carl de Boor and Peter Wirth. Stuttgart: B. G. Teubner.

Vita Willbaldi episcopi Eichstetensis et vita Wynnebaldi abbatis Heidenheimensis auctore sanctimoniale Heidenheimsensis, O. Holder-Egger, MGH Scriptores 15/1 (1887; reprint 1992). Hannover: Hahn, 80-117.

\section{Secondary literature}

CHRYSOS, EVANGELOS (1987). "Die Nordgrenze des byzantinischen Reichesim 6. bis 8. Jahrhundert". Die Völker Südosteuropas im 6. bis 8. Jahrhundert, Hänsel, Bernhard. Berlin: Südosteuropa-Gesellschaft, 2740 .

-, (2007). "Settlements of Slavs and Byzantine sovereignty in the Balkans". Byzantina Mediterranea. Festschrift für Johannes Koder zum 65. Geburtstag, Belke, Klaus, Ewald Kislinger, Andreas Külzer and Maria Stassinopoulou. Vienna: Böhlau, 2007, 123-135.

CURTA, FLORIN (2008). "The making of the Slavs between ethnogenesis, invention, and migration". Studia Slavica et Balcanica Petropolitana, 6, 2, 155-172.St. Petersburg.

-, (2011). "Sklaviniai and ethnic adjectives: a clarification". Byzantion Nea Hellás 30, 85-98. Santiago.

DRONKE, PETER (1984). Women Writers of the Middle Ages. A Critical Study of Texts from Perpetua (d. 203) to Marguerite Porete (d. 1310). Cambridge/New York: Cambridge University Press.

GOTTSCHALER, EVA (1973). Hugeburc von Heidenheim. Philologische Untersuchungenzu den Heiligenbiographien einer Nonne des achten Jahrhunderts. Munich: Bei der Arbeo-Gesellschaft. 
GKOUTZIOUSKOSTAS, ANDREAS (2015). "The term ' $\Sigma \kappa \lambda \alpha v \eta v i ́ \alpha$ ' and the use of epithets which derive from ethnic names in the historical work of Theophylact Simocatta". International Scientific Conference "Cyril and Methodius: Byzantium and the World of the Slavs", Thessaloniki 2015. Tachiaos, Antonios-Emilios N. Thessaloniki: Dimos, 639-648.

KRIVUSHIN, I. V. (1991). "Stasis po Feofilaktu Simokatte, Evagriu i Feofanu (voennyi miatezh 588-589 gg.)”. Iz istorii Vizantii $i$ vizantinovedeniia. Mezhvuzovski sbornik, Kurbatov, G. L. Leningrad: Izdatel'stvo Leningradskogo universiteta, 47-57.

MALINOVSKÁ (VEREŠOVÁ), NORA (2013). "Geographical concepts of Sclavinia in historical sources from the sixth to the fourteenth century, with an emphasis on the Moravian-Pannonian and South Slavic traditions". Slovensko a Chorvátsko. Historické paralalely a vztahy do roku (1780), Homza, Martin Ján Lukačka and Neven Budak. Bratislava/Zagreb: Katedra slovenských dejín, Filozofická fakulta Univerzity Komenského v Bratislave/Filozofski fakultet Sveučilišta u Zagrebu, 60-65.

MORFAKIDIS FILACTÓS, M. AND CASA OLEA, M. (2009). Fuentes bizantinas sobre los Eslavos. Granada: Centro de Estudios Bizantinos, Neogriegos y Chipriotas.

NOBLE, THOMAS F. X., AND HEAD, THOMAS (1995). Soldiers of Christ. Saints and Saints' Lives from Late Antiquity and the Early Middle Ages. University Park: Pennsylvania University Press.

OLAJOS, TERÉZ (1982). "Quelques remarques sur le style de Théophylacte Simocatta". XVI. Internationaler Byzantinistenkongreß. Akten. II, Hörandner, Wolfram, Carolina Cupane and Ewald Kislinger, vol. 3. Vienna: Verlag der Österreichische Akademie der Wissenschaften, 157164.

-, (1988). Les sources de Théophylacte Simocatta historien. Leiden: Brill.

-, (1990-1992). "La langue littéraire grecque du VIIe siècle d'après l'examen de l'oeuvre de Théophylacte Simocatta". Acta Antiqua Academiae Scientiarum Hungaricae, 38, 177-186. Budapest.

PATOURA, SOPHIA (2002). "Ho Dounabes stis istoriographikes peges kata ten periodo tes metanasteuseos ton laon: mythoi kai pragmatikoteta". Historikogeographika, 9, 399-412.Thessaloniki.

POHL, WALTER (2002). Die Awaren. Ein Steppenvolk im Mitteleuropa 567822 n. Chr. Munich: C. H. Beck.

RONIN, VLADIMIR K. (1995). “Zhitie Villibal'da, episkopa Eikhshtettskogo”. Svod drevneishikh pis'mennykh izvestii o slavianakh, Ivanov, Sergei A, Gennadii G. Litavrin and Vladimir K. Ronin, vol. 2. Moscow: "Vostochnaia literatura" RAN, 439-440. 
TREADGOLD, WARREN (2007). The Early Byzantine Historians. Basingstoke/New York: Palgrave Macmillan.

-, (2013). The Middle Byzantine Historians. Basingstoke/New York: Palgrave Macmillan.

WHITBY, MARY AND WHITBY, MICHAEL (1986). The History of Theophylact Simocatta. An English Translation with Introduction and Notes. Oxford: Clarendon Press.

WOŁOSZYN, MARCIN (2014). Theophylaktos Simokates und die Slawen am Ende des westlichen Ozeans - die erste Erwähnung der Ostseeslawen? Cracow: Instytut Archeologiii Etnologii Polskiej Akademii Nauk. 